\title{
SUMBANGAN PENULIS WANITA DALAM SEJARAH PENULISAN KREATIF DI SABAH ${ }^{1}$
}

\author{
Asmiaty Amat \& Lokman Abdul Samad
}

\begin{abstract}
ABSTRAK
Negeri Sabah telah melahirkan ramai penulis berbakat termasuk penulis wanita. Kehadiran dan sumbangan penulis wanita dalam penulisan kreatif memberi impak tersendiri, bukan sahaja kepada sejarah penulisan kreatif di negeri Sabah malah nama penulis wanita yang dilahirkan di negeri tersebut seiring dengan kemampuan penulis di peringkat kebangsaan. Antara beberapa nama yang menjadi penulis yang dapat disetandingkan, bahkan memberi sumbangan besar dalam sejarah kesusasteraan Malaysia merupakan penulis wanita Sabah. Nama Azmah Nordin dan Ruhaini Matdarin sebagai contoh tidak asing lagi. Mereka sering menjuarai pertandingan atau hadiah sastera yang dianjurkan oleh badan kerajaan dan swasta. Kepelbagaian tema serta kelebihan penulis wanita Sabah yang hidup dalam persekitaran multietnik memberikan ruang yang besar kepada mereka untuk menonjolkan kemampuan berkarya. Artikel ini akan memberi tumpuan kepada sejarah dan sumbangan penulis wanita dalam penulisan kreatif.
\end{abstract}

Kata kunci: Penulis wanita Sabah, penulisan kreatif, kesusasteraan, sejarah, sumbangan.

\begin{abstract}
Sabah has produced many talented writers, women notwithstanding. The presence of women writers in the field of creative writing has not only impacted the history of creative writing in the state but also on a national level. Among them are Nordin Azmah and Ruhaini Matdarin whose fame and talent always precedes them. The numerous awards and literary prizes they have won in the government and private sectors testifies to their skills and talent as writers. The diversity of themes and multicultural backdrop in Sabah have provided these women distinct advantages. This article will focus on the history and contributions of women writers in creative writing specifically in Sabah.
\end{abstract}

Keywords: Sabah women writers, creative writing, a literature, history, contribution. 


\section{PENGENALAN}

Sejarah perkembangan kesusasteraan Melayu moden di negeri Sabah telah bermula pada sekitar tahun 1950-an sejak surat khabar menjadi wadah menampung karyakarya penulis Sabah ketika itu. Melalui ruangan 'Our Romanised Malay Corner' dalam akhbar Sabah Times ${ }^{2}$, cerpen pertama yang ditulis oleh Bismal Yusuf telah diterbitkan pada 26 Jun $1954 .{ }^{3}$ Perkembangan surat khabar, persatuan-persatuan penulis yang ditubuhkan di negeri Sabah serta penglibatan guru dan pekerja yang dibawa dari Semenanjung Tanah Melayu menjadi pemangkin perkembangan kesusasteraan, khususnya penulisan cerpen dan puisi di negeri ini. Penubuhan Dewan Bahasa dan Pustaka Cawangan Sabah (DBPS) menjadi batu asas yang kukuh dalam melonjakkan lagi peranan Sabah sebagai sebuah negeri yang telah menyumbang kepada perkembangan kesusasteraan tanah air.

Perkara paling menarik dalam sejarah perkembangan kesusasteraan di negeri Sabah ialah peranan dan sumbangan yang diberikan oleh penulis-penulis wanita. Sungguhpun bilangan penulis wanita Sabah tidak seramai penulis lelaki, kualiti karya mereka telah memberi kesan besar dan tersendiri dalam sastera Sabah hatta sejarah kesusasteraan tanah air. Tulisan ini bertujuan untuk memaparkan sejarah perkembangan penglibatan penulis wanita Sabah dan sumbangan mereka dalam penulisan kreatif.

\section{Perkembangan dan Sumbangan Penulis Wanita Sabah dari 1950-an hingga 1990-an}

Sejarah awal perkembangan sastera Sabah pada tahun 1950-an telah mencatatkan kemunculan seorang penulis wanita pertama Sabah bernama Azizah Lakin. Penulis kelahiran Singapura ini menggunakan nama pena Zahati. Tulisan beliau yang telah dikesan ialah puisi yang berjudul 'Bayangan Asmara Ini' (North Borneo News \& Sabah Times (NBN@ST), 26 November 1956), 'Hanya Bayangan' (Sabah Times, 22 Oktober 1956), 'Guru' (NBN \& ST, 3 Ogos 1956 ) dan 'Kesunyian Kalbu' (Majalah AGABA, Julai 1957). Cerpen Zahati juga diterbitkan pada tahun 1956 berjudul 'Nasihat Dari Kawan' yang tersiar dalam akhbar NB \& ST pada 5 November.

Kepedulian beliau dalam kesusasteraan membawa beliau terlibat dalam bidang lakonan drama radio bersama Angkatan Gaya Baru (AGABA) ${ }^{4}$ yang dipimpin oleh Allahyarham K.Bali. Azizah Lakin hanya muncul dalam tempoh masa yang singkat tetapi impak kemunculannya melayakkan beliau digelar sebagai penulis wanita pertama negeri Sabah. 
Pada tahun 1963, Sabah merdeka dan menyertai Semenanjung Tanah Melayu dan Sarawak membentuk Malaysia. Senario ini memberi kesan dan momentum baharu dalam perkembangan sastera di negeri Sabah. Pertumbuhan percetakan surat khabar dan penerbitan karya dalam radio pada tahun 1960an turut menambah wadah penampungan karya penulis seperti akhbar Daily Ekspress, Sinar Usia dan Fajar Sabah. Jika pada tahun 1950-an, jumlah cerpen yang terbit hanya sebanyak 65 buah, jumlah penerbitan cerpen telah meningkat kepada lima kali ganda kerana pada tahun 1960-an penerbitan cerpen telah menjangkau 440 buah (Ismail Abbas, 1995: 12).

Senario ini turut memungkinkan kemunculan penulis yang mengikuti jejak langkah Azizah Lakin seperti Suhani S (Datin Hajah Noraini Datuk Seri Panglima Haji Salleh), Dayang Salmah Salam dan Salbiah Mahmud. Selain Dayang Salmah Salam yang aktif menulis sehingga kini, Suhani S merupakan tokoh penulis wanita yang telah memberi sumbangan besar dalam dunia persuratan di negeri Sabah.

Karya pertama beliau berupa cerita pendek yang disiarkan di radio Sarawak pada tahun 1962. Pada sekitar tahun 1970-an hingga 1980-an, beliau aktif menulis dalam surat khabar tempatan seperti Sabah Times dan Daily Express. Selain daripada itu, karya-karya beliau turut diterbitkan dalam antologi Haram, Gema Lembah Kinabalu dan Siapakah Antara Kita.

Selain berkarya, Datuk Noraini turut terlibat secara aktif dalam berpersatuan. Beliau bersama Khalik Zaman mendirikan PERPESA pada 22 Mac 19645. PERPESA menunjukkan komitmen melalui pelbagai aktiviti pembangunan penulis muda pada masa itu sehingga Noraini dan rakan-rakan seperti Jamdin Buyong (Datuk), Khalik Zaman (Datuk) dan Dzulkiflee Abdul Hamid (Datuk) menubuhkan Badan Bahasa Sabah (BAHASA) pada 19 Mac 1970. Bagi mengenang jasa bakti yang telah diberikan oleh beliau, DBP Cawangan Sabah telah memilih Datuk Noraini sebagai penerima Hadiah Penghargaan Penulis pada tahun 1990 dan menerima Anugerah Tokoh Penyair Islam Sabah pada tahun 1999.

Pada sekitar tahun 1968 seorang penulis wanita Sabah, iaitu Zaiton Ajmain mula memperlihatkan kemampuannya sebagai penulis muda yang bakal mencorakkan sejarah perkembangan penulisan di negeri Sabah dan Malaysia amnya. Sungguhpun beliau yang sehingga kini masih bergiat aktif dalam dunia sastera Sabah lebih senang menggunakan nama pena seperti Zarni, Zaiton Aji, Norzaiton Aji dan Azjalailatul Farhan, penulis ini akhirnya lebih dikenali melalui penggunaan nama sendiri. Bertugas di DBP cawangan dan menamatkan kerjaya 
di DBP Kuala Lumpur sekitar tahun 2010 memberikan ruang dan peluang besar kepada Hajah Zaiton untuk mengembangkan bakat dan kredibiliti sekali gus menjadi pembimbing kepada penulis-penulis muda yang lain. Selain menulis puisi dan cerpen, Hajah Zaiton Ajmain turut menjadi editor dan menulis esei kritikan.

Karya-karya beliau disiarkan dalam akhbar dan majalah tempatan dan kebangsaan seperti majalah Wadah dan Dewan Sastera selain yang diterbitkan dalam antologi seperti Berhati Nabi Berwajah Ibu (1979), Ujana Laut, Ujana Hati (1989), Nyanyi dari Desa (1990), Jalan ke Hujung Taman (1991) dan kumpulan puisi perseorangan, iaitu Bagai Layang-layang (1991). Setanding dengan kemampuan dan kredibiliti penulis wanita lain, puisi beliau sering kali menerima Hadiah Sastera Sabah dan Hadiah Sastera Perdana. Tokoh penulis yang tidak asing dalam dunia persuratan Sabah dan tanah air ini telah dianugerahkan Tokoh Penyair Islam Sabah pada tahun 1995. Anugerah paling berprestij dalam bidang yang diceburinya lebih 50 tahun ini sangat berbaloi apabila beliau dianugerahkan Doctor of Literature oleh World Assembly of Arts and Culutre, Amerika Syarikat pada tahun 2013.

Sumbangan Hajah Zaiton Ajmain juga menjangkau pada penubuhan persatuan penulis. Bersama Marzuki Ali, Sairah Antin, M.Y Nast, Sharif Asmawan dan Rosnah Awang, mereka menubuhkan Anak Seni ${ }^{6}$ pada tahun 1970-an. Anak Seni ditubuhkan sebagai alternatif kepada BAHASA dan GAPURA serta memfokuskan kepada aktiviti penulis-penulis muda ketika itu. Mereka sempat menerbitkan antologi berjudul Suara Asas (1981).

Rakan seangkatan Hajah Zaiton yang gigih berkarya pada tahun-tahun 1970an hingga akhir tahun 1990-an ialah Mariam Omar, Sairah Antin (allahyarhamah), Rubiah Dullah dan Rubiah Nordin. Mariam Omar sangat produktif pada tahun-tahun 1980-an sehingga akhir 1990-an kini sudah menyepikan diri. Karya-karya Mariam Omar diterbitkan dalam surat khabar tempatan dan buletin (kini majalah) WADAH selain diterbitkan dalam antologi penulis seperti Lambaian Kinabalu, Gema Membelah Gema, Surat dari Pulau, Suara ASAS, Bagai Camar di Lautan, Rantau Utara (terbitan DBP Brunei), Siapakah Antara Kita dan antologi persendirian berjudul Ababil. Mariam Omar juga merupakan penulis Sabah yang pernah beberapa kali memenangi Hadiah Sastera Sabah melalui penulisan puisi dan cerpen.

Seorang lagi tokoh penulis wanita Sabah yang tidak boleh dipandang sepi ialah Allahyarhamah Sairah Antin. Semasa hayat beliau yang pernah bertugas sebagai pegawai kebudayaan, di Yayasan Sabah, beliau pernah meneraju BAHASA $^{7}$. Beliau bergiat bukan sahaja dalam penulisan cerpen dan puisi, malah 
terlibat dalam penulisan skrip drama radio dan pentas. Puisi dan cerpen beliau tersiar di surat khabar tempatan dan arus perdana seperti Dewan Sastera, Dewan Masyarakat, Mastika, Perempuan, Horizon (Indonesia), selain diterbitkan dalam antologi seperti Mutiara Diri, Gema Membelah Gema, Cahaya, Titian Kasih, Tasbih Hayat dan Teluk Perkasihan, Calar Mimpi (cerpen), Menanti Subuh (cerpen) dan Kemarau Semusim (skrip drama radio).

Sejak DBP cawangan Sabah ditubuhkan pada tahun 1977, DBPS aktif membantu perkembangan bakat penulis dan membuka ruang untuk mereka berkarya. DBPS turut membantu kegiatan persatuan-persatuan penulis yang wujud di negeri itu. Malah, pada tahun 1986 DBPS telah menerbitkan majalah WADAH dan Jendela Sabah bagi menampung karya penulis-penulis Sabah. Program-program galakan yang dikendalikan oleh DBPS seperti program penulisan, penataran sastera, program Anak Angkat Dewan termasuklah menganjurkan peraduan menulis dan menerbitkan karya penulis. Semua usaha ini merancakkan lagi perkembangan sastera di Sabah dan sekali gus menghasilkan lebih banyak penulis muda.

Bersabit dengan aktiviti tersebut, Sabah telah melahirkan nama-nama besar penulis wanita dan mereka menjadi penyumbang kepada sejarah persuratan tanah air. Pada pertengahan tahun 1980-an, tiga orang penulis wanita yang sering diperkatakan peminat sastera tempatan ialah Azmah Nordin, Obasiah Usman dan Sitti Rahmah Ibrahim. Bermula dengan penulisan cerpen, ketiga-tiga orang wanita ini akhirnya muncul sebagai penulis novel wanita yang dilakar dalam sejarah sastera tanah air.

Obasiah Usman yang ada kalanya menggunakan nama pena Arnida Ho merupakan pengarang wanita yang berasal dari Kudat. Beliau mendapat pendidikan awal di daerah Beluran dan sekitar Bandar Sandakan. Sehubungan itu, karya-karya awal beliau seperti novel Malisiah dan Bertaut berlatarbelakangkan daerah Sandakan.

Obasiah ialah penulis novel wanita Sabah yang pertama. Beliau telah mengikuti sayembara mengarang novel Islam pertama di Sabah, anjuran Majlis Ugama Islam Sabah (MUIS) dengan kerjasama Biro Bahasa, Jabatan Ketua Menteri Sabah pada tahun 1982. Naskhah “Malina” karya Obasiah Usman telah dinobatkan sebagai pemenang tempat kedua. Novel-novel beliau yang lain ialah Malisiah, Bertaut (1988), Pungkad (1989) dan Detik-Detik yang Menggugat (2009). Keaktifan beliau berkarya dalam tahun-tahun 1980-an hingga tahun 1990-an kini mula langka kerana Obasiah lebih memfokuskan perhatian terhadap rumah tangga beliau. 
Perkara ini tidak sama dengan rakannya Sitti Rahmah G Ibrahim yang masih bertahan tanpa rasa lelah dan jemu. Sungguhpun karya-karya Sitti Rahmah masih berada pada tahap yang sama sebagaimana penglibatan awal beliau, karyanya sentiasa hadir dan penglibatan beliau yang aktif dalam BAHASA menjadikan beliau tidak pernah hilang dalam sejarah penulisan wanita di Sabah. Penglibatan beliau bukannya baharu kerana penulis ini mula menulis sejak dari tahun 1979 lagi. Karya beliau, terutamanya cerpen banyak diterbitkan di surat khabar tempatan, selain dimuatkan dalam antologi Bagai Camar di Lautan, Orang Baru (1986), Pulut Kuning Daging Rendang (1986) dan Serpihan Musim (1991). Beliau turut menerbitkan kumpulan cerpen sendiri yang berjudul Kelalagan. Walaupun cerpen beliau belum pernah menembusi Hadiah Sastera Perdana, beberapa cerpen beliau telah mendapat hadiah sastera Sabah.

Sitti Rahmah juga menulis skrip drama radio dan teater selain novel. Sejak penghasilan Hijrah (1989), Sitti Rahmah turut menerbitkan novel Rungkaian Kasih (1994), Kuntum Berputik, Kasihku Bersemi di Sini (2004) dan Mengusai Impian (2007). Novel terbaru beliau berjudul Taklik Cinta (2012) telah memenangi Hadiah Kedua Sayembara Menulis Novel Sabah Siri I pada tahun 2009/2010. Novel-novel Sitti Rahmah menonjolkan budaya etnik Bajau dan Murut dan kegigihan wanita tempatan Sabah menghadapi kemelut hidup. Sebuah antologi cerpen berjudul Angin dari Timur memuatkan cerpen-cerpen yang ditulis oleh empat orang pengarang wanita Sabah yang diterbitkan sekitar tahun 1980-an hingga 1990-an dalam akhbar. Buku tersebut membabitkan penulisan cerpen Zaiton Ajmain, Sitti Rahmah G Ibrahim, Mariam Omar dan Sitti Hadiah Abdul Mutalib.

Kemuncak kepada penglibatan penulis wanita dalam sejarah sastera Sabah ialah melalui penglibatan Azmah Nordin. Azmah yang berasal dari Kedah, telah bermastautin di Sabah sejak tahun 1973. Berpeluang menghadiri bengkel penulisan yang dianjurkan oleh DBPS membangkitkan semangat beliau untuk berkarya. Bermula dengan cerpen berjudul 'Bosan' yang diterbitkan pada tahun 1987 dalam majalah WADAH, Azmah Nordin memperkasakan dirinya sebagai penulis wanita Malaysia tersohor dengan barisan novel seperti Kukui (1989), Dukanya Abadi (1990), Dari Dalam Cermin (1992), Debur Menerpa (1992), Halusinasi (1995), Menongkah Lumrah (1996), Awang Kirana Mudir Besar (1996), Pantai Kasih (1994), Singgahmata (1999), Syumul (1999), Mega Nisaa (2005) dan Lara (2012). Novel Dari Dalam Cermin (1992) pernah memenangi tiga hadiah sastera sekali gus, iaitu Hadiah Pertama Peraduan Mengarang Novel, Hadiah Sastera Sabah dan Sastera Perdana. Demikian juga novel Menongkah Lumrah pernah memenangi Hadiah Sastera Sabah dan Perdana pada tahun 
penilaian 1997, sementara Syumul menerima Hadiah Khas peraduan anjuran Esso-Gapena pada tahun 1999. Novel-novel tersebut belum termasuk novel kanak-kanak, novel remaja dan novel berasaskan cerita rakyat.

Cerpen-cerpen yang dihasilkan Azmah Nordin juga bukan sedikit. Selain cerpen-cerpen yang bertebaran dalam akhbar tempatan dan arus perdana, Azmah menerbitkan kumpulan cerpen, iaitu Singkowoton (1994), Wizurai (1997), Kasih Seputih Kemboja (2001) dan Titian Gelora (2005). Kebijaksanaan penulis ini mengembangkan persoalan dalam cerpen hingga membentuk sebuah novel adalah satu rahsia yang kini mula diikuti oleh beberapa orang penulis wanita generasi muda seperti Ruhaini Matdarin dan Dayangku Mastura. Azmah ialah penulis Sabah yang paling banyak memenangi Hadiah Sastera Sabah dan Hadiah Sastera Perdana Malaysia menerusi kategori cerpen dan novel. Contohnya cerpen 'Kekasih' memenangi Hadiah Sastera Sabah 2012, manakala cerpen 'Usus' telah memenangi Hadiah Sastera Perdana Malaysia pada tahun 2011.

Ketekalan Azmah Nordin berkarya turut membentuk semangat dan jati diri kepengarangannya. Menulis banyak karya bermutu dalam tempoh yang relatif singkat bukan menjadi satu fenomena yang membanggakan dalam sejarah perkembangan sastera Sabah. Azmah juga menjadi pilihan (selepas Allahyarham Ismail Abbas) yang telah menerima anugerah Sea Write Award di Thailand pada tahun 2009 bagi mewakili Malaysia. Pemilihan beliau sebagai penerima anugerah bukan sahaja mengangkat kredibiliti penulis wanita di Malaysia, malah telah mengangkat nama sastera Sabah ke persada kebangsaan dan serantau. Tidak mustahil jika penulis yang telah dilantik sebagai munsyi dewan ini akan diangkat sebagai Sasterawan Negara wanita pertama Malaysia. Pada masa kini, penulis ini giat menjadi guru kepada penulis-penulis muda, khususnya penulis wanita dalam penulisan kreatif.

Sumbangan penulis wanita dalam sejarah sastera juga tidak sesekali melupakan libatsama dan sumbangan Welin Ebal, Mistirine Radin, Jaliha Jaman, Ariah Judah, Suzita Janaun, Asmiah Ajmain, Sitti Hadiah Abdul Muttalib, Laila Elok, Sasjira, Jariah Taha, Amelly Ann Kasing, Julia Unggai, Salbiah Jabrin, Sahara Jais, Noor Aishah Maidin, Ony Latifah, Norjanah MA, Hasnah Anjam, Hamidah Kassam dan Raya Erom. Kesemua mereka ini sama ada terlibat dalam penulisan cerpen, puisi, novel kanak-kanak, novel thriller dan remaja atau kedua-duanya.

Sungguhpun kalangan penulis yang disenaraikan ini tidak memberi impak yang besar, penglibatan mereka turut memeriahkan sejarah sastera Sabah. Terdapat dalam kalangan mereka yang muncul dan aktif, kemudian tidak lagi aktif akibat 
kesibukan menguruskan rumah tangga dan kerjaya masing-masing. Tidak kurang pula yang masih gigih berkarya dalam skala yang lebih kecil ataupun membuat kemunculan secara bermusim melalui tulisan dalam akhbar atau antologi cerpen dan puisi bersama rakan penulis yang lain.

\section{Penulis Wanita Mutakhir}

Pada era mutakhir ini, banyak penulis pelapis wanita muncul dalam arena penulisan kreatif negeri Sabah. Mereka ialah Kuniah Anthonia Gilung, Noraini Osman, Angela Engkuan, Siti Aisyah Mad Saad, Rafidah Abdul Ghani, Martinah Obod, Ismi Nailofar@ Hadijah Mahmud, Ramlah Abdul Rashid, Dayangku Mastura Pengiran Ismail, Pena Alam@ @ita Robert Rawantas, Nur Mustika, Azridah PS, Ruhaini Matdarin, Faridah Abd. Hamid, Amina Ali, Kathirina Tati, Rasimi Linggang, Rozelin Vitalis, Siba Nita S, Badariah Arbin, Norjanah MA, Aina Syafiqa Abdullah dan Jessy Mojuru. Senarai penulis wanita ini menyumbang dalam penulisan cerpen, puisi dan novel.

Sebagaimana kelompok penulis era 1980-an, terdapat dalam kalangan mereka yang muncul dengan satu atau dua buah karya yang memenangi hadiah sastera tetapi akhirnya hilang dalam sejarah penulisan kreatif. Terdapat pula kalangan penulis tersebut yang telah memulakan penulisan sejak tahun 1990an dan hanya menyerlah pada dekad-dekad mutakhir ini seperti Kathirina Tati. Namun, beberapa orang daripada mereka pula ialah penulis muda yang akhirnya mencipta nama sehingga menjadi terkenal di peringkat kebangsaan.

Nama yang sering disebut-sebut oleh peminat sastera sejak akhir ini ialah Ruhaini Matdarin dan Dayangku Mastura. Nama mereka menyerlah sejak karya mereka memenangi hadiah sastera di peringkat kebangsaan. Di awal pembabitannya, beliau telah menempa kejayaan apabila memenangi tempat pertama dalam peraduan mengarang cerpen sempena kempen Budi Bahasa Budaya Kita anjuran Kementerian Hal Ehwal Wanita (KEKWA) (2006).

Nama Ruhani Matdarin telah memuncak dalam arus sastera perdana setelah memenangi anugerah novel remaja pada tahun 2008, menerusi novel berjudul Jendela Menghadap Jalan. Novel tersebut memenangi tempat kedua Hadiah Sastera Kumpulan Utusan-Exxon Mobil. Seterusnya, novel Waris Pejuang (2012) beliau telah memenangi Hadiah Sastera Novel Remaja 2011. Sebelum itu, novel Gadis Adikara (2007) telah memenangi Hadiah Sastera Sabah pada tahun penilaian yang sama. 
Hasil karya penulis ini turut memenangi tempat kedua Sayembara Menulis Novel Sabah anjuran Lembaga Kebudayaan Negeri Sabah dan BAHASA pada tahun 2010 melalui novel Nisan (2011), sekali gus memenangi Hadiah Sastera Sabah pada tahun penilaian tersebut. Karya-karya beliau yang lain ialah Nurbalkis (2010), Pesona Sandora, Ketika Cinta Berlari (2012), Pencuri Cinta (2012), Dalam Getar Waktu (2012) dan novel-novel terbitan Institut Terjemahan Buku Malaysia (ITBM) seperti Dukana (2013) dan Di Seberang Jalan dan Anatomi Rupert (2014). Novel remaja beliau berjudul Kotak turut memenangi Hadiah Sastera Kumpulan Utusan 2012 dan baru-baru ini sekali lagi mengungguli hadiah pertama kategori novel remaja Hadiah Sastera Kumpulan Exxon Mobil 2013 menerusi karya berjudul Cinta Perang Bariga. Ruhaini tersenarai sebagai salah seorang daripada 200 orang penulis yang memperoleh royalti tertinggi dalam tahun 2010 bagi penulis yang berkarya di bawah penerbitan PTS Media Group.

Selain menulis novel (termasuk novel remaja), Ruhaini Matdarin yang kadangkala menggunakan nama pena Aini Effariza turut menulis cerpen dan puisi. Kumpulan cerpen beliau berjudul Misi Penyepit Kain (2013) dan Melawan yang Mustahil (2013). Kumpulan cerpen Melawan yang Mustahil telah mendapat hadiah pertama pertandingan menulis kumpulan cerpen anjuran ITBM pada tahun 2013. Ketekalan penulis ini dilihat menyamai konsistensi Azmah Nordin dan beliau berpotensi untuk terbang lebih tinggi daripada 'senior'nya. Pada tahun 2015 ini, sekali lagi Ruhaini Matdarin memenangi Hadiah Saguhati Pertandingan Menulis yang dianjurkan ITBM dan Berita Harian untuk tahun 2014 melalui kumpulan cerpen berjudul 'Jenaka Si Darah Lagenda' dan novel berjudul Trivia. Karya terbaru beliau berjudul Ajal (2015) diterbitkan oleh Penerbit UTM Press mengisahkan seorang suami yang cuba menyelamatkan isteri yang menghidap tumor.

Pencapaian yang boleh dikatakan hebat daripada Ruhaini Matdarin memberikan impak tersendiri. Kesannya bukan sahaja kepada dunia penulisan wanita tanah air, malah nama Ruhaini kini mendahului nama penulis-penulis negeri Sabah sendiri.

Dayangku Mastura juga merupakan penulis pelapis yang sejak akhir-akhir ini, bukan sahaja aktif berkarya malah karya-karyanya telah mendapat tempat dalam arus perdana. Sejak cerpennya yang berjudul 'Kulintangan' memenangi tempat Pertama Peraduan Menulis Cerpen Sedco-BAHASA pada tahun 2009, beliau semakin menunjukkan bakatnya dalam dunia penulisan. Cerpen beliau juga sering memenangi hadiah utama dalam peraduan menulis anjuran Exxon 
Mobil. Contohnya pada tahun 2011, cerpen 'Bakau Tetap Teguh' menerima Hadiah Sastera Kumpulan Utusan dan cerpen 'Cahaya Takdir' menang hadiah yang sama pada tahun 2013. Kumpulan cerpennya berjudul Langit Runtuh turut memenangi Hadiah Saguhati Peraduan Menulis Cerpen, Novel dan Puisi yang dianjurkan ITBM pada tahun 2013.

Selain menulis cerpen, DK Mastura turut menulis skrip drama dan novel. Pada tahun 2012, skrip dramanya berjudul 'Menara Biru' telah memenangi Hadiah Sastera Perdana dan tahun 2013 novel remaja berjudul Helaian Linangkit memenangi hadiah tempat kedua peraduan menulis novel remaja anjuran DBP Sabah. Novel beliau yang lain ialah Cahaya di Jendela yang diterbitkan ITBM pada tahun 2013 .

Kathirina Susanna Tati ialah penulis yang mewakili etnik Kadazandusun selain Welin Ebal yang pernah aktif menulis novel sebelum ini. Kathirina mula berkecimpung dalam dunia penulisan sejak dari tahun 1995 apabila cerpennya tersiar dalam akhbar Borneo Post dan pada penilaian hadiah sastera Sabah tahun 1996/1997, cerpen beliau berjudul 'Menanti Maut Menggamit Pulang' dinobatkan sebagai salah satu karya yang memenangi hadiah saguhati. Setakat ini Kathirina memiliki kumpulan puisi berjudul Mahligai Pasir (2010), selain antologi puisi Kuntum Kasih dan Kelarai. Cerpen-cerpen Kathirina dikumpulkan dalam kumpulan cerpen Sogit (2009) dan Tangis Buliga (2012). Selain menulis puisi dan cerpen, Kathirina juga menulis novel dan cerita kanak-kanak. Novel beliau berjudul Pagi di Hujung Senja (2013) dan novel Vusak Putih (2012) telah memenangi Hadiah dalam sayembara menulis novel anjuran Lembaga Kebudayaan Sabah dengan kerjasama DBP Cawangan Sabah pada tahun 2012.

Nama penulis wanita generasi baharu yang mempunyai potensi untuk berkembang sebagaimana rakan-rakan mereka yang lain ialah Ramlah Abdul Rashid, Pena Alam, Faridah Abdul Hamid, Nur Mustika, Azridah S dan Ismi Nailofar@Hadijah Mahmud. Jika penulis-penulis generasi baharu ini konsisten dan mempertingkatkan kepelbagaian tema dan teknik dalam penulisan mereka, tidak mustahil mereka akan mengikuti jejak rakan mereka seperti Ruhaini Matdarin.

\section{Tema dan Persoalan Karya Penulis Wanita}

Bagi penulisan puisi, tema dan persoalan yang dikemukakan oleh pengarang wanita tentulah bercapah dan tidak hanya memfokuskan kepada satu-satu isu yang ketara. Bermula daripada pengalaman diri sendiri yang merangkumi kecintaan dan kasih sayang, kesedaran dan keakuran sebagai insan kerdil mengharapkan 
kasih sayang Tuhan hinggalah kepada isu-isu kemasyarakatan, pembangunan, kemiskinan, warisan budaya dan kecintaan kepada tanah air menjadi mauduk puisi. Melalui sentuhan jiwa rasa dan sudut pandang wanita, karya yang dinyatakan itu disalurkan secara metafora mahupun secara berterus terang. Bertepatan dengan sifat wanita sebagai manusia berhati lembut dan penyayang, tentu sahaja misi mengangkat tema dan persoalan berkenaan kasih sayang, keamanan dan kedamaian sebagai satu misi yang penting.

Berbanding cerpen dan novel, tendensi untuk membicarakan dunia domestik wanita masih kukuh dalam kalangan penulis wanita. Contohnya karyakarya yang ditulis oleh Sitti Rahmah G Ibrahim, Azmah Nordin, Mariam Omar, Jaliha Jaman, Hajah Asmiah Ajmain, Sitti Hadiah Mutalib dan Kathirina Tati. Melalui kumpulan cerpen atau novel yang ditulis sama ada oleh Azmah Nordin, Welin Ebal, Sitti Rahmah atau Kathirina Tati misalnya, tumpuan terhadap permasalahan wanita menghadapi cabaran dunia pekerjaan dan masyarakat masih menjadi isu utama dalam karya mereka.

Penulis-penulis ini lebih selesa membicarakan perihal jagat raya kewanitaan. Karya mereka menjurus kepada penceritaan tentang nostalgia, pengalaman biologi, pencitraan wanita yang seharusnya ditonjolkan yang berkait rapat dengan emosi dan pemikiran, kepincangan hidup, ketaatan sebagai anak perempuan sehinggalah kepada masalah domestik wanita sebagai ibu dan suri rumah tangga. Perkara ini wajar memandangkan hanya wanita yang mampu menyelami jiwa wanita berbanding lelaki. Justeru, kegagalan dalam menampilkan soal perasaan dan keinginan wanita menjadi pemangkin kepada kewujudan dan ketekalan mereka dalam arena penulisan.

Azmah Nordin mendahului penulis wanita lain dalam membawa isu berkenaan wanita dan permasalahan gender. Watak wanita yang diangkat oleh pengarang ini kerap kali digambarkan sebagai watak yang menentang patriarki, yakni persaingan keupayaan dan kemampuan dengan watak lelaki yang sering merendah-rendahkan kemampuan dan menafikan hak wanita dalam masyarakat.

Permasalahan gender tersebut dituntun seiring dengan permasalahan global dalam dunia perniagaan, politik, perubatan, telekomunikasi, komputer dan restoran. Pada awal-awal kehadiran beliau seperti dalam novel Dukanya Abadi (1989), wanita dalam karyanya diperlihatkan terperangkap dalam adat budaya perkahwinan. Namun, akhirnya pencitraan watak wanita dalam karya Azmah dirombak menjadi wanita yang bukan lagi duduk diam merenung masa silam yang kelam, menyesali diri dan orang lain tetapi telah ditampilkan menjadi wanita 
yang berani menongkah lumrah menghadapi apa jua cabaran yang diberikan dalam dunia kerjaya dan alam rumah tangga. Walaupun demikian, wanita yang dipaparkan oleh kebanyakan penulis wanita Sabah didapati masih bersifat objektif dan menekankan status quo lelaki. Bagi penulis wanita, tidak semua lelaki kejam dan mempunyai tanggapan yang sendeng terhadap wanita. Masih wujud lelaki yang bertimbang rasa, menghormati wanita malah diberi tempat pada kedudukan yang tinggi di mata penulis wanita.

Terdapat pengarang yang secara dasarnya mula keluar daripada zon selesa dalam memperkatakan tentang pengalaman wanita semata-mata. Ruhaini Matdarin sebagai contohnya lebih seimbang dalam berkarya. Sungguhpun beliau turut berbicara tentang dunia wanita, beliau juga mengimbangi karyanya dengan melihat lelaki daripada sudut pandang wanita. Melalui kumpulan cerpen "Melawan yang Mustahil" (2013) contohnya, hanya sebuah cerpen sahaja yang mengisahkan tentang wanita. Selainnya, beliau mengangkat pelbagai isu kecil yang relevan pada zaman kontemporari. Isu tokek dan penipuan, cacing, pemandu teksi, pengumpul kotak, kerani, ahli sukan diadun dengan nilai kesabaran, kejujuran dan amanah yang semuanya merupakan isu biasa. Namun, isu biasa itu diangkat beliau pada satu titik fokus kepada keperitan dan kesusahan masyarakat menangani krisis ekonomi dewasa ini.

Jika keunggulan Azmah terletak pada tumpuannya terhadap permasalahan wanita dan kewanitaan, identiti Ruhaini Matdarin terletak pada pemikiran yang segar, bersifat realiti kontemporari yang bervariasi. Perkara ini yang menjadikan karya beliau berlainan daripada penulis wanita lain yang sedia ada. Sesungguhnya ketekalan, identiti dan kepelbagaian dilihat semacam satu penanda aras bagi membentuk seorang penulis.

Satu lagi perkara yang memberi nilai tambah kepada penulis wanita Sabah ialah pelestarian latar masyarakat dan budaya tempatan Sabah dalam konteks dunia kerjaya yang rencam memberi semacam trademark kepada penulis-penulis Sabah amnya. Perkara ini turut didukung oleh penulis-penulis wanita seperti Kathrina Tati, Kuniah Anthony Gilung dan Pena Alam. Jika dalam tempoh sepuluh tahun yang lalu, Welin Ebal mewakili penulis Dusun Kimaragang yang begitu taat memperincikan budaya etnik Kadazandusun, kini penulis generasi baharu Sabah ada Kathirina Tati dan Kuniah Anthony Gilung yang menyerlah dalam memaparkan latar dan budaya Kadazandusunnya. Pena Alam pula membina gaya kepengarangan yang tersendiri dengan budaya Murut Timugon yang cukup indah dan menarik. 
Jika segala unsur ini diadun kemas dengan pemikiran yang ingin disalurkan, serta teknik yang teratur dan bersifat kontemporari nescaya tidak mustahil lebih banyak penulis wanita Sabah yang akan menjadi penulis berkaliber di peringkat kebangsaan kelak.

Dari segi teknik penceritaan, penulisan wanita juga telah memperlihatkan peningkatan yang membanggakan. Bermula daripada teknik konvensional, pengarang wanita telah mula meneroka dan arif dalam penceritaan yang menggunakan teknik aliran bawah sedar yang dianggap sebagai teknik 'avantgarde', selain berterusan memperbaiki gaya bahasa. Jika gaya bahasa penulis Sabah pada tahun-tahun 1970-an hingga 1990-an masih dalam paras yang sederhana, penulis wanita kini mula tampil dengan gaya bahasa yang setaraf malah lebih baik jika dibandingkan dengan penulis mapan yang lain.

Dengan barisan nama-nama penulis wanita dan karya-karya yang menerobos bentuk, gaya dan pemikiran baharu, penulis-penulis wanita di Sabah hari ini dilihat telah membina satu barisan yang kuat dalam perkembangan sastera mutakhir. Tidak mustahil apabila setiap kali pengumuman hadiah sastera, nama penulis wanita Sabah disebut sebagai sebuah negeri yang sangat produktif melahirkan penulis berbakat.

\section{KESIMPULAN}

Secara keseluruhannya, kehadiran penulis wanita Sabah didapati telah memberi impak yang berbeza dalam sejarah sastera di negeri Sabah dan amnya di Malaysia. Kepelbagaian etnik dan latar belakang penulis memberi ruang kepada mereka untuk menonjolkan jati diri dan budaya tradisi dalam arus perdana. Penglibatan mereka dalam bidang penulisan kreatif selain mengangkat kredibiliti wanita yang sering kali dilupakan oleh pihak lelaki, pengarang wanita Sabah didapati telah menonjolkan keberanian dan kegigihan dalam bidang yang diceburi oleh mereka. Boleh dikatakan banyak penulis wania Sabah memiliki pemikiran yang besar dalam berkarya serta kekuatan dalam pengolahan naratif yang bukan sahaja setanding dengan penulis wanita dari Semenanjung Malaysia, malah telah mencapai tarafnya yang tersendiri. 


\section{NOTA}

${ }^{1}$ Dibentangkan dalam Seminar Wanita anjuran KESUMBA (Kelab Surirumah dan Wanita Universiti Malaysia Sabah), Dewan Bahasa dan Pustaka Sabah dan Puteri UMNO Sabah.

2 Sabah Times ialah akhbar harian (kecuali hari Ahad) yang pertama kali diterbitkan di Kota Kinabalu pada tahun 1954. Penerbit dan ketua pengarang akhbar tersebut ialah Donald A. Stephens. Surat khabar tersebut hanya mengandungi empat halaman dengan menggunakan tiga jenis bahasa, iaitu Inggeris, Melayu dan Kadazandusun. Oleh sebab pasaran surat khabar yang tidak menguntungkan dan mengelakkan persaingan sesama sendiri, Donald Stephens membeli hak 'North Borneo News' dan menggabungkannya dengan akhbar Sabah Times. Gabungan itu melahirkan akhbar North Borneo \& Sabah Times (NBN\& ST) sehingga awal tahun 1967. Pada mulanya akhbar ini hanya memiliki empat halaman dan dijual dengan harga 10 sen senaskhah. Akhbar ini masih menggabungkan tiga jenis bahasa, iaitu bahasa Inggeris, Melayu dan Kadazandusun. Ruangan ORMC (Our Romanised Malay Corner) yang hanya separuh halaman juga dikekalkan dengan menggabungkan bahasa Kadazandusun dan bahasa Melayu. Perkara tersebut menjelaskan bahawa bahasa Melayu di Sabah sebelum merdeka tidak dititikberatkan dan sama tarafnya dengan bahasa Kadazandusun. Hal ini berkait dengan pemilik akhbar tersebut yang memperjuangkan bangsa dan bahasa Kadazandusun kerana orang Kadazandusun ialah penduduk majoriti di Sabah. Halaman tersebut pula bukan dikhususkan untuk penyiaran bahan sastera, melainkan penyiaran berita-berita dalam bahasa Melayu yang diterjemahkan daripada bahasa Inggeris. Walau bagaimanapun, pada masa-masa tertentu, penerbitan cerpen dan puisi dapat dilihat melalui ruangan tersebut. Pada tahap awal, ruangan ORMC dikendalikan oleh pengarang sambilan seperti Idrus Zainuddin, Idris Echin dan Thamby Hashim Ali.

${ }^{3}$ Kenyataan bahawa Bismal Yusof sebagai pengarang cerpen pertama Sabah telah dipertikaikan oleh Ungku Maimunah (1985). Menurut beliau, cerpen Bismal Yusof tidak layak diangkat sebagai cerpen pertama di Sabah kerana pengarangnya tidak berjaya menyelesaikan tulisan tersebut sebagaimana yang dijanjikan pengarangnya dalam keluaran cerpen yang pertama. Tambah beliau lagi, cerpen pertama yang dikeluarkan sepenuhnya ialah cerpen 'Kakak Siti Janda Muda' yang ditulis oleh Teruna Lara Sandakan pada 10 Julai 1954 (NBN \& ST, 10 Julai 1954). Namun, Asmiaty Amat (2010: 45) menyatakan bahawa cerpen Bismal Yusof tersebut telah mampu berdiri sebagai sebuah cerpen tanpa ada sambungan melayakkan cerpen ini diangkat sebagai cerpen pertama Sabah.

${ }^{4}$ AGABA ialah sebuah persatuan yang diterajui oleh K.Bali dan rakan-rakannya seperti Donald Stephens. Ditubuhkan pada tahun 1957, persatuan ini merupakan persatuan sosiobudaya yang terawal di Sabah dan mendapat sambutan menggalakkan daripada masyarakat di sekitar Kota Kinabalu. Persatuan tersebut telah didaftarkan secara rasmi pada tahun 1958 di bawah undang-undang Kerajaan Borneo Utara. Kebanyakan ahli AGABA ialah guru lepasan Maktab Kent, wartawan dan pegawai kerajaan. Selain Donald Stephens dan K. Bali, ahli-ahli AGABA yang lain ialah Zakaria Gunn, Jaafar Hussain dan Dayang Salmah Tamin.

${ }^{5}$ Setelah AGABA yang ditubuhkan pada tahun 1957 tidak lagi aktif, ahli-ahlinya yang terdiri daripada pensyarah dan guru Maktab Kent telah menubuhkan Angkatan Penulis Melayu Sabah (APMS).

${ }^{6}$ Persatuan tersebut sempat menerbitkan dua siri majalah yang diberi nama 'API-API' yang digunakan untuk menampung karya penulis muda pada tahun 1981 dan 1982.

7 Allahyarhamah adalah satu-satunya penulis wanita yang pernah menerajui Badan Bahasa Sabah (BAHASA) pada sekitar awal tahun 1990-an.

\section{RUJUKAN}

Asmiaty Amat. (2005). (tidak diterbitkan). Penulis pelbagai kaum Sabah. Laporan Projek Penulis Pelbagai Kaum Malaysia. Kuala Lumpur: Dewan Bahasa dan Pustaka. . (2007). Feminisme in Geni Jora by Abidah El-Khalieqy and Menongkah Lumrah by Azmah Nordin: A comparative study. Jurnal Malay Literature, Vol. 20. No. 2.

. (2010). Mediasi dalam perkembangan novel Sabah. Tesis peringkat PhD. Akademi Pengajian Melayu, Kuala Lumpur. Tidak diterbitkan.

Azmah Nordin. (1990a). Kukui. Kuala Lumpur: Dewan Bahasa dan Pustaka \& Kementerian Pendidikan Malaysia. 
Azmah Nordin. (1990b). Dukanya abadi. Kuala Lumpur: Dewan Bahasa \& Pustaka \& Kementerian Pendidikan Malaysia.

. (1992a). Dari dalam cermin. Kuala Lumpur: Dewan Bahasa dan Pustaka $\&$ Kementerian Pendidikan Malaysia. . (1992b). Debur menerpa. Kuala Lumpur: Dewan Bahasa dan Pustaka \& Kementerian Pendidikan Malaysia. . (1994). Pantai kasih. Shah Alam: Penerbit Fajar Bakti. .(1996a). Awang Kirana mudir besar. Shah Alam: Penerbit Fajar

Bakti.

Pustaka. (1996b). Menongkah lumrah. Kuala Lumpur: Dewan Bahasa dan . (1997). Singgahmata. Shah Alam: Penerbit Fajar Bakti. . (1998). Halusinasi. Kuala Lumpur: Dewan Bahasa dan Pustaka. . (1999). Syumul. Kuala Lumpur: Dewan Bahasa dan Pustaka. . (2006). Mega nisa. Kuala Lumpur: Dewan Bahasa dan Pustaka.

Ismail Abbas, Matlin Dullah et al. (1997). Kumpulan esei perkembangan novel di Sabah. Kota Kinabalu: Dewan Bahasa dan Pustaka Sabah.

Ismail Abbas, Othman Puteh \& Shuhaibun Yussuf. (1995). Kumpulan esei perkembangan cerpen di Sabah. Kota Kinabalu: Dewan Bahasa dan Pustaka Sabah.

Obasiah Usman. (1986). Bertaut. Kuala Lumpur: Dewan Bahasa dan Pustaka \& Kementerian Pelajaran Malaysia. (1987). Malisiah. Kuala Lumpur: Dewan Bahasa dan Pustaka \& Kementerian Pendidikan Malaysia. . (1989). Pungkad. Kuala Lumpur: Dewan Bahasa dan Pustaka \& Kementerian Pendidikan Malaysia.

Sitti Rahmah G. Ibrahim. (1990). Hijrah. Kuala Lumpur: Dewan Bahasa dan Pustaka \& Kementerian Pendidikan Malaysia. . (1994). Rungkaian kasih. Kuala Lumpur: Dewan Bahasa dan Pustaka.

Welin Ebal. (1996). Pelangi kehidupan. Kuala Lumpur: Dewan Bahasa dan Pustaka . (2005). Seluang melaut. 2005. Kuala Lumpur: Dewan Bahasa dan

Pustaka.

\begin{abstract}
Akhbar
North Borneo News \& Sabah Times. 26 Jun 1954.

North Borneo News \& Sabah Times. 10 Julai 1954

North Borneo News \& Sabah Times, 28 Januari, 1955.

North Borneo News \& Sabah Times, 8 Februari, 1955.

North Borneo News \& Sabah Times, 19 Februari, 1955.

North Borneo News \& Sabah Times, 18 Mac, 1955.

North Borneo News \& Sabah Times, 10 Ogos, 1955.

North Borneo News \& Sabah Times, 3 Ogos 1956.

North Borneo News \& Sabah Times, 21 September, 1955.

North Borneo News \& Sabah Times, 4 Oktober, 1955.
\end{abstract}


North Borneo News \& Sabah Times, 20 Oktober, 1955.

North Borneo News \& Sabah Times, 25 dan 26 Oktober, 1955.

North Borneo News \& Sabah Times, 1 dan 2 November, 1955.

North Borneo News \& Sabah Times, 8 dan 9 November, 1955.

North Borneo News \& Sabah Times, 26 November 1955. 